\title{
INTERPRETANDO O MUNDO
}

\section{Rodrigo de Medeiros Silva' (30/04/17)}

\author{
Kaigang nos ensinou, que oralidade \\ É a fala das árvores, rios, animais...
}

Não está em livros, mas com seus ancestrais.

A linguagem da dita modernidade,

Não lê corretamente esses seus sinais,

Jovens estudam cinco anos e são os tais,

Mas ele aprendeu com gente de idade...

Estudaram, assim, a ciência da vida,

Ah, estudaram por oitenta ou mais anos.

Agora, vem homem branco com seus enganos,

Faz da oralidade ciência preterida,

Um mundo que vem trazendo perdas e danos,

Ah, como eles são estreitos, tão insanos,

É tanta coisa, que querem deixar perdida.

1 Advogado Popular e poeta éMestre em Direitos Humanos pela UniRitter, Porto Alegre/RS (2019); graduou-se em Direito pela Universidade de Fortaleza-UNIFOR, Fortaleza/CE (2003); e especialista em Direito Civil e Processual Civil, pelo Instituto de Desenvolvimento Cultural IDC, em Porto Alegre-RS (2016). Integra os grupos de estudos da UniRItter Direitos Humanos e Violência e Direitos Humanos e Literatura. Fez cursos de extensão em Direitos Humanos pela Unicap, em Recife-PE (2004/2005), e em Direito Civil e Processo Civil pela UnB, em Brasília-SF (2006). É membro e fundador do Instituto de Pesquisa Direitos e Movimentos Sociais- IPDMS e conselheiro da Seção Sul do Instituto. Foi Consultor da UNESCO para o Marco Regulatório das Organizações da Sociedade Civil, junto à Secretaria de Governo da Presidência da República (2015/2016). Ainda foi assessor no Relatório da Carcinicultura da Câmara dos Deputados (2004/2005) e do relator da CPMI da Terra (2005/2006). Participa da Rede Nacional de Advogadas e Advogados Populares-RENAP, Fórum Justiça, Articulação Justiça e Direitos Humanos- JusDH e do Coletivo de Advogados Ambientalistas do Rio Grande do Sul. 